\title{
StRATEGY AIMS TO LIFT ORGAN DONATIONS
}

$T$ he Australian Coordinating Committee on Organ Registries and Donation (ACCORD) was formed by the Australian Health Ministers' Advisory Council in October 1989 to develop and implement strategies and provide national coordination to try to overcome the low organ donation rate in Australia.

The committee consists of a chairman, NSW Chief Health Officer Dr Sue Morey, and seven members. An executive officer, Mrs Michael McBride, and a part-time secretary, Mrs Suzanne Bowers, are employed in the secretariat, which is in the office of the Chief Health Officer, NSW Health Department.

A publicity officer was employed for a 12-month term to develop and implement a national publicity and marketing strategy to raise awareness of organ donation, targeting both the public and health professionals. This campaign involved:
- creating the ACCORD profile as a reference point for organ donation issues;
- producing a quarterly newsletter (sponsored by Sandoz Aust). Five thousand copies are distributed nationally to people on the ACCORD mailing list; establishing a resource list of speakers for authoritative information;
- establishing an extensive mailing list;
- maintaining a monthly media log to measure interest in organ donation. It averaged 30 entries a month except for June 1992, when there were 117 entries in response to a national television advertisement and the inaugural National Organ Donation Awareness Day;
- a 24-hour toll-free donor information line - 018 018995 which received 1200 calls in the first two months and is sponsored by Telecom Mobilenet;
- launching a TV advertising campaign - GIVE \& LET LIVE - to make the subject of organ donation 'acceptable' and generate discussion. It included supporting printed materials (leaflets, posters and bumper stickers), carrying a consistent national message: decide to be an organ donor and tell your family. This message was agreed to by relevant groups, including the Australian Kidney Foundation, National Heart Foundation, Road Traffic Authorities, Health Department and professional organisations;
- National Organ Donation Awareness Day, on the first Friday in June each year, with activities including thanksgiving services in all States;
- utilising religious and ethnic specialised media; and
- developing a recipient information kit, with up- to-date information on organ and tissue donation and transplantation in Australia.

ACCORD facilitated public and professional research surveys to identify reasons for the low donor rate in Australia. Results received from a study conducted in NSW hospitals (supported by grants from the NSW

\section{FIGURE 3}

\section{CADAVER DONOR KIDNEY \\ PROCUREMENT, AUSTRALIA \\ AND STATES 1984-92}

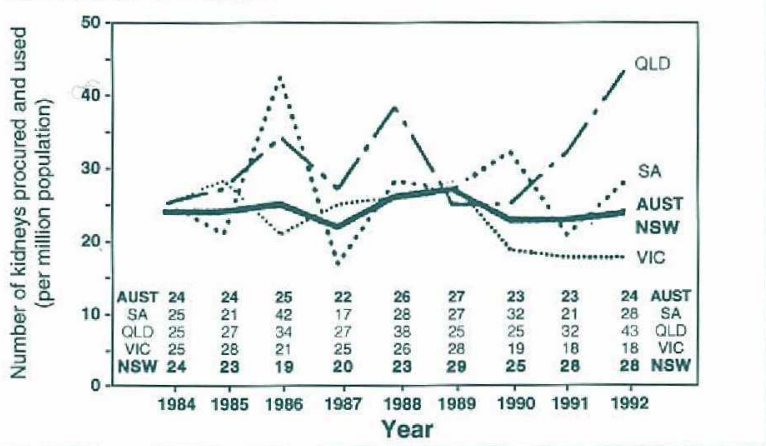

Health Department and Sandoz Aust) suggest that donor organ shortage is due not to a lack of potential donors, but rather to a failure to turn potential donors into actual donors ${ }^{1}$.

Australia, with a voluntary system for organ donation (opting in), has one of the lowest donation rates in the developed world - 12 per million population ( $\mathrm{pmp}$ ) in 1990 and 1991 . This equates to 204-209 actual organ donors, respectively.

As seen on the graph produced by the Renal Transplant Unit at Princess Alexandra Hospital in Brisbane (Figure 1), rates vary between the States. Based on cadaveric kidneys procured and transplanted, Queensland has the highest rate, with $32 \mathrm{pmp}$ in 1991 and $43 \mathrm{pmp}$ in the first six months of 1992, giving an organ donation rate of 16 pmp and 22 pmp respectively.

Victoria has the lowest rate of kidney procurement (18 pmp), giving an organ donation rate of $9 \mathrm{pmp}$.

Rates of organ donation also vary in overseas countries, e.g. in $1991^{2}$

- countries with an opting in system:

$$
\begin{array}{ll}
\text { Netherlands } & 24.3 \text { donors pmp } \\
\text { United Kingdom } & 15.8 \text { donors pmp }
\end{array}
$$

- countries with an opting out system:

$$
\begin{array}{ll}
\text { Belgium } & 20.0 \text { donors pmp } \\
\text { Denmark } & 1.7 \text { donors pmp }
\end{array}
$$

Regardless of the system in place for organ donation, constant publicity and education are required to keep both the public and health professionals aware of the need for organs and tissue for transplantation. Waiting lists continue to grow and in Australia there are about 3000 people waiting for transplantation. Of those needing heart or liver replacement, about 20 per cent will die while waiting for a suitable donor.

In 1992 ACCORD conducted an extensive review of progress in improving organ donation in Australia. This review culminated in the development of a national strategic management plan for raising organ donation rates over the next three to five years. 


\section{Vitamin K prophylaxis}

Continued from page 15

The dilemma confronting the Department also faces clinicians and parents of newborn infants. There is no clear immediate solution. The NHMRC/ACP/RACOG statement acknowledges the need for more information. It recommends that epidemiological surveillance of $\mathrm{HDN}$ and childhood cancer be enhanced and that research be undertaken into the pharmacology and potential carcinogenicity of vitamin $\mathrm{K}$ preparations. The Epidemiology and Health Services Evaluation Branch has a major role in the former.

Michael Frommer, Deputy Director, Epidemiology and Health Services Evaluation Branch, NSW Health Department

Elisabeth Murphy, Medical Officer, Family and Child Health, Service Development and Planning Branch, NSW Health Department

Timothy Churches, Medical Epidemiologist, Epidemiology and Health Services Evaluation Branch, NSW Health Department

David Henderson-Smart, Head, Department of Perinatal Medicine, King George V Hospital, Sydney, and Professor of Perinatal Medicine, The University of Sydney

1 Golding J, Paterson M, Kinlen LJ. Factors associated with childhood cancer in a national cohort study. Br J of Cancer, 1990; 62:304-8. 2 Golding J, Greenwood R, Birmingham K, Mott M. Childhood cancer, intramuscular vitamin $\mathrm{K}$, and pethidine given during labour. $\mathrm{Br} \mathrm{Med} J$ $1992 ; 305: 341-346$

3 Calman KC, Moores T. Circular: Prophylaxis against Vitamin K Deficiency Bleeding in Infants. Numbers FL/CMO(92)20 and

FL/CNO(92)14. Department of Health, London, December 1992.

4 Draper GJ, Stiller CA. Letter: Intramuscular vitamin K and childhood cancer. Br Med $\mathrm{d}$, 1992, 305:709.

5 Miller RW. Letter: Vitamin K and childhood cancer. Br Med J, 1992 , 305:1016-7.

6 National Health and Medical Research Council, Australian College of Paediatrics and Royal Australian College of Obstetricians and

Gynaecologists. Joint Statement and Interim Recommendations on

Vitamin K Prophylaxis for Haemorrhagic Disease in Infancy. NH\&MRC, Canberra, January 1993

\section{Organ donations}

Continued from page 16

The plan's priorities are to:

- develop and implement health professional education/information programs; increase public awareness and acceptance for organ donation; and provide national coordination and linkage to these activities.

ACCORD is developing a national Australian donor hospital information program involving organisations concerned with health professionals' educational processes.

Michael McBride, Executive Officer.

1. Hibberd $\mathrm{AD}$ et al. $\mathrm{Br}$ Med J, May 1992; 304:1339-43.

2. Transplant. Council of Europe. Vol 04, July 1992

\section{INFECTIOUS DISEASES}

\section{TIMELINESS AND COMPLETENESS OF REPORTING}

T he following table lists the number of weekly reports made to the Epidemiology and Health Services

Evaluation Branch in the past month, i.e. from Epiweek 1 to Epiweek 3.

Several Public Health Units experienced network problems during January. Although this affected their ability to transfer notification data centrally, it did not affect response to each notification.

\section{TABLE 5}

\section{NUMBER OF WEEKLY REPORTS MADE TO EPIDEMIOLOGY BRANCH, JANUARY 1993}

\begin{tabular}{lcc|} 
Public Health Unit & Number & Status \\
\hline Central/Southern Sydney & 2 & Complete \\
Eastern Sydney & 2 & Complete \\
South Western Sydney & 1 & Incomplete \\
Western Sector & 2 & Complete \\
Northern Sydney & 2 & Complete \\
Central Coast & 0 & Incomplete \\
Illawarra & 0 & Incomplete \\
Hunter & 2 & Complete \\
North Coast & 1 & Complete \\
New England & 1 & Incomplete \\
Orana and Far West & 1 & Incomplete \\
Central West & 2 & Complete \\
South-West & 2 & Complete \\
South-East & 2 & Complete \\
\hline
\end{tabular}

\section{TYPHOID FEVER IN NORTH COAST REGION}

A woman aged 30 was admitted to a North Coast hospital on January 14, 1993 with fever, diarrhoea and a history of vomiting for two days. No rash was observed. The woman had returned from a visit to India with her husband and three children. The youngest child, aged 10 months, had similar symptoms and was also admitted to hospital.

Stool cultures from the mother grew Salmonella typhi, and the case was notified to the Public Health Unit on January 18. Antibiotic therapy was initiated for both mother and child. Stool specimens were taken from all family members. The infant was notified to the PHU on January 20 when a positive stool specimen result became available.

It was thought unnecessary to contact the airline as the neither case was thought to be contagious until after their return home. Hospital infection control staff advised other concerned relatives in close contact with the family of the necessary precautions. Hospital staff were advised that isolation was not required.

It could not be confirmed whether typhoid immunisation had been received. The source of the infection was thought to be a contaminated water supply in India. (Contributed by Tim Sladden, North Coast Public Health Unit) 